Institute of $\mathbf{F}_{\text {ood and }} \mathbf{A}_{\text {gricultural }} \mathbf{S}_{\text {ciences }}$

\title{
Haviland's Subterranean Termite, Coptotermes havilandi Holmgren (Insecta: Isoptera: Rhinotermitidae) ${ }^{1}$
}

Rudolf H. Scheffrahn and Nan-Yao Su²

\section{Introduction}

Coptotermes havilandi is a very damaging termite and a threat to wooden structures wherever it occurs. As one might expect, Coptotermes havilandi is similar in many respects to C. formosanus Shiraki, the Formosan subterranean termite. General information related to the life history, damage, and management of $C$. formosanus is applicable to $C$. havilandi and can be obtained from our sister publication on $C$. formosanus. This report highlights important distinguishing characteristics of $C$. havilandi.

\section{Distribution}

Coptotermes havilandi is endemic to Southeast Asia. Over the last century, human activity has spread this termite far beyond its native range. It was collected in the Marquesas Islands (Pacific Ocean) in 1932, and Mauritius and Reunion (Indian Ocean) in 1936 and 1957, respectively. In the New World tropics, this species was first reported in Brazil in 1923 and in Barbados in 1937. Recent collections from other West Indian islands include Antigua,
Barbuda, Cuba, Grand Turk, Guadeloupe, Little Cayman, Montserrat, Nevis, Providenciales, Puerto Rico (San Juan), and St. Kitts. It has also been collected in southern Mexico and possibly occurs on Jamaica and Virgin Gorda, B.V.I.

In 1996, C. havilandi was collected for the first time in the continental United States from a storefront and a church in Miami, Florida. In 1999, a colony of C. havilandi was discovered infesting a waterfront house in Key West, Florida. Dade County, Florida, is the only known locality where $C$. formosanus and $C$. havilandi have both become established. In 2000, three additional homes in another neighborhood of Key West were found to be infested with $C$. havilandi. Elsewhere in the world, these two widely introduced species are geographically isolated. Coptotermes formosanus usually invades mildly temperate climates (to 35 degrees north latitude in the U.S.), while C. havilandi is limited to more tropical localities as noted above. In the West Indies, $C$. havilandi has invaded some natural woodland habitats. In Florida, it has been collected only from structures, ornamental trees near structures, and boats. Two private boats in Florida have been found with

1. This document is EENY-128 one of a series of Featured Creatures from the Entomology and Nematology Department, Florida Cooperative Extension Service, Institute of Food and Agricultural Sciences, University of Florida. Published: April 2000. This document is also available on Featured Creatures Website at http://creatures.ifas.ufl.edu. Please visit the EDIS Website at http://edis.ifas.ufl.edu. Additional information on these organisms, including many color photographs, is available at the Entomology and Nematology Department website at http://entnemdept.ifas.ufl.edu/.

2. Rudolf H. Scheffrahn, professor and Nan-Yao Su, professor, Entomology and Nematology Department, Ft. Lauderdale REC, University of Florida, Ft. Lauderdale, FL.

The Institute of Food and Agricultural Sciences is an equal opportunity/affirmative action employer authorized to provide research, educationa information and other services only to individuals and institutions that function without regard to race, color, sex, age, handicap, or national origin. For information on obtaining other extension publications, contact your county Cooperative Extension Service office. Florida Cooperative Extension Service/Institute of Food and Agricultural Sciences/University of Florida/Christine Taylor Waddill, Dean. 
shipboard infestations, one arriving from Jamaica and the other from Virgin Gorda. These boats were docked in Ft. Pierce and Hollywood, respectively. Shipboard infestations are the most likely means of human dispersal of this pest as the result of on-board dispersal flights that reach land.

\section{Description and Identification}

Superficially, soldiers of $C$. havilandi resemble those of $C$. formosanus. Both species have a large opening on the forehead called the fontanelle. When viewed from above, both also share tear drop-shaped heads. Microscopic examination of the fine hairs on the head reveals diagnostic differences. Coptotermes havilandi soldiers have one pair of hairs near the rim of the fontanelle, while in C. formosanus, two pairs originate around the fontanelle. Additionally, the lateral profile of the top of the head just behind the fontanelle shows a weak bulge in $C$. havilandi that is absent in C. formosanus. As with C. formosanus, $C$. havilandi soldiers constitute about 10 to 15 percent of foraging groups, aggressively bite when challenged, and exude a white mucous-like secretion from the fontanelle.

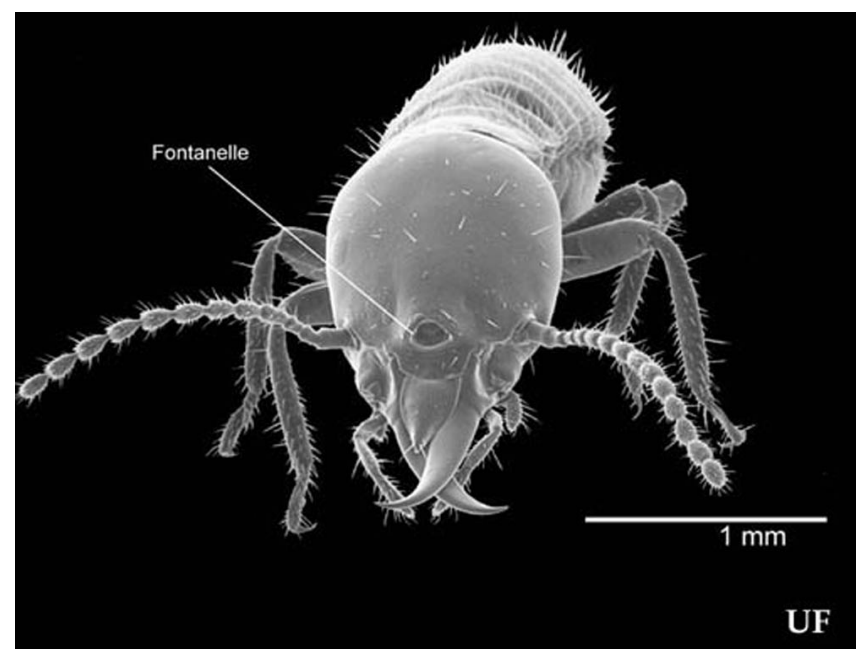

Figure 1. Formosan subterranean termite, Coptotermes formosanus Shiraki, soldier showing the ovoid head shape and large fontanelle that are characteristic of all Coptotermes species. Credits: Rudolf H. Scheffrahn, University of Florida

The alates of $C$. havilandi are slightly smaller than those of $C$. formosanus (total length with wings about 13-14 mm vs.14-15 mm, and maximum head width $1.4 \mathrm{~mm}$ vs. $1.5 \mathrm{~mm}$, respectively). The head, pronotum, and dorsal abdomen of $C$. havilandi alates

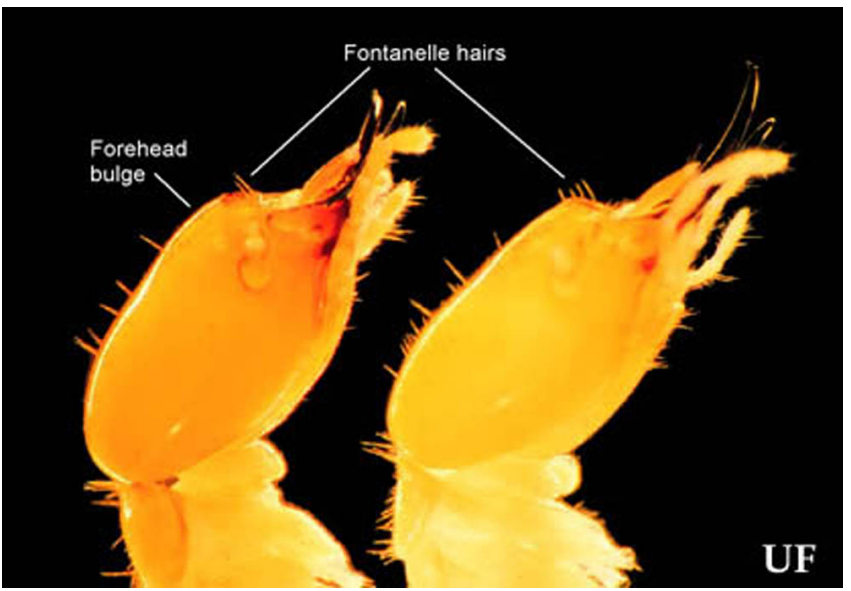

Figure 2. Lateral view of soldier head capsules of Coptotermes havilandi Holmgren (left) and C. formosanus Shiraki. Antennae removed for clarity. Credits: Rudolf $\mathrm{H}$. Scheffrahn, University of Florida

are brown, while those of $C$. formosanus are entirely a lighter yellow-brown or orange-brown. The darker pigmentation of the $C$. havilandi head provides a contrasting background for two light patches on the face called antennal spots. In C. formosanus the antennal spots are barely, if at all, visible. The length of wing hairs is somewhat shorter in C. havilandi than in $C$. formosanus.

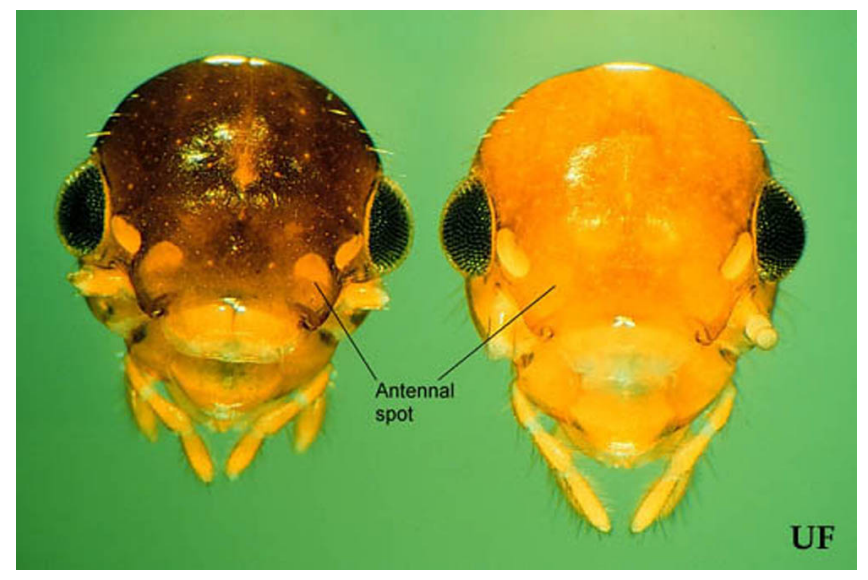

Figure 3. Alate head capsules of Coptotermes havilandi Holmgren (left) and $C$. formosanus Shiraki. Antennae partially removed for clarity. Credits: Rudolf H. Scheffrahn, University of Florida

\section{Life History}

Like $C$. formosanus, C. havilandi dispersal flights or "swarms" occur at dusk or at night when large numbers of alates leave the colony. In Florida and the West Indies, $C$. havilandi flights have been record between February and April. The $C$. havilandi flights end about when the $C$. formosanus flight-season 


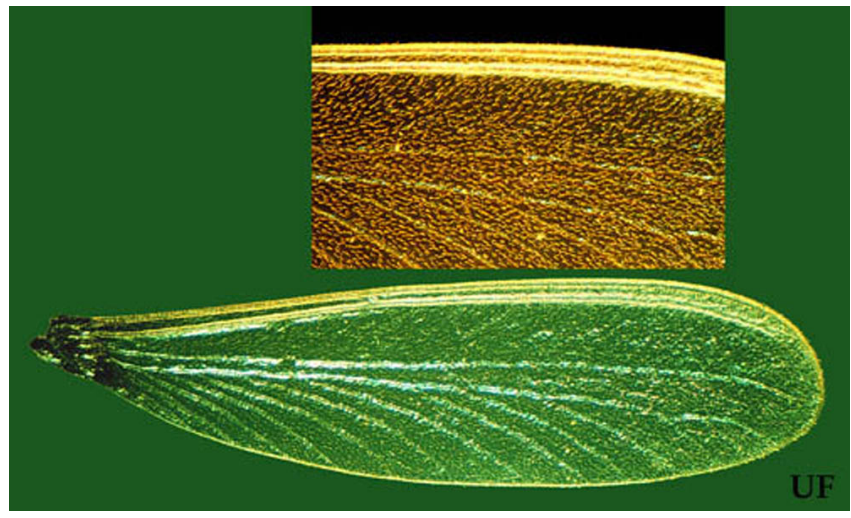

Figure 4. Coptotermes havilandi Holmgren wing (inset shows close-up of hairs on wing membrane). Credits: Rudolf H. Scheffrahn, University of Florida

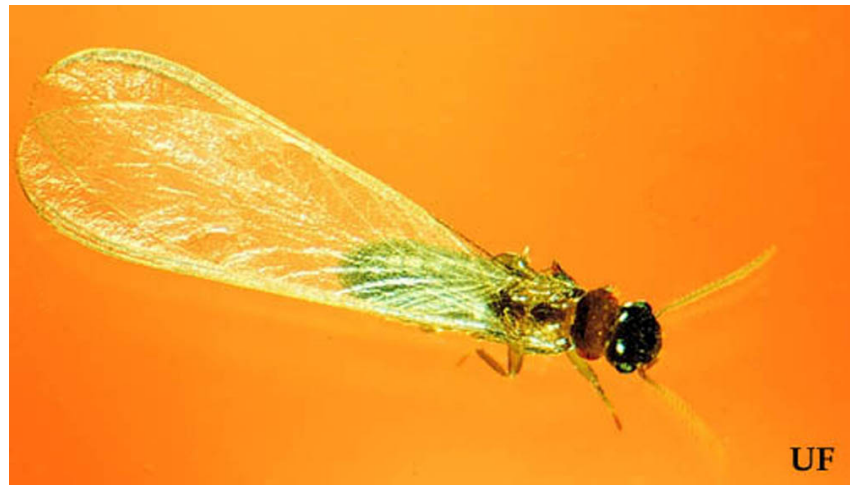

Figure 5. Coptotermes havilandi Holmgren alate. Credits: Rudolf $\mathrm{H}$. Scheffrahn, University of Florida

begins. Porch lights, indoor lights, and video monitors often attract the alates inside, especially when doors and unscreened windows are opened. When large numbers (100s-1,000s) of alates are found indoors, their presence is usually indicative of a structural infestation. Alates flying indoors are unlikely to find the moist wood/soil substrate they need for successful colonization, and succumb quickly to desiccation. It is likely, however, that most dispersal flights will produce a few new colonies that may become a damage threat in future years.

\section{Damage}

Like other structure-infesting species of Coptotermes, damage resulting from a $C$. havilandi infestation can become severe in a matter of months, especially when a structure is invaded by a large, mature colony. Dispersal flights, foraging tubes, or damage are usually the first indications of an infestation. Advanced stages of infestation are

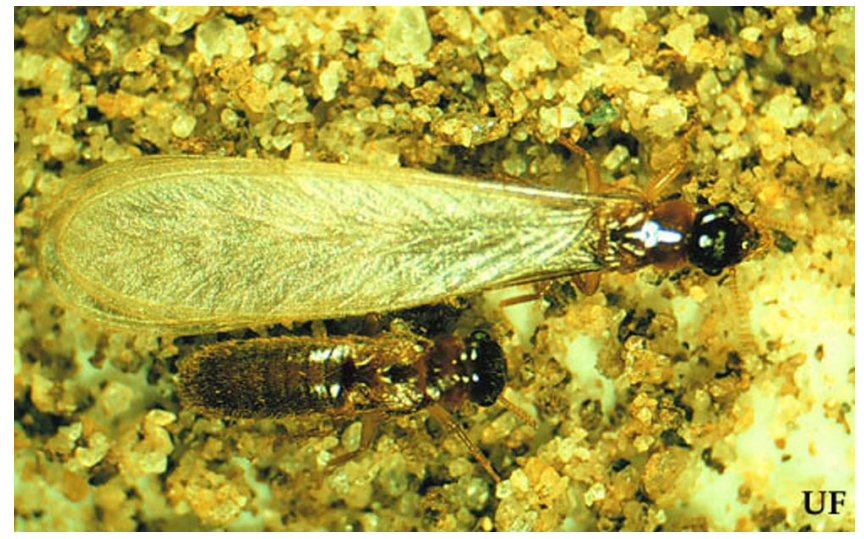

Figure 6. Coptotermes havilandi Holmgren alate (top) and dealate. Credits: Rudolf H. Scheffrahn, University of Florida

indicated by the incorporation of nest material (carton) in hollowed wood or existing voids.

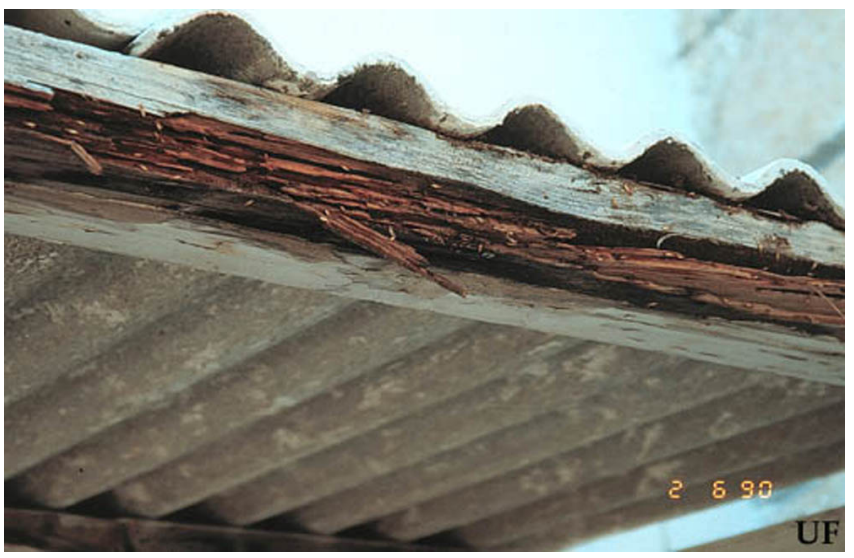

Figure 7. Damage by Coptotermes havilandi Holmgren to fascia, Grand Turk Island. Credits: Rudolf H. Scheffrahn, University of Florida

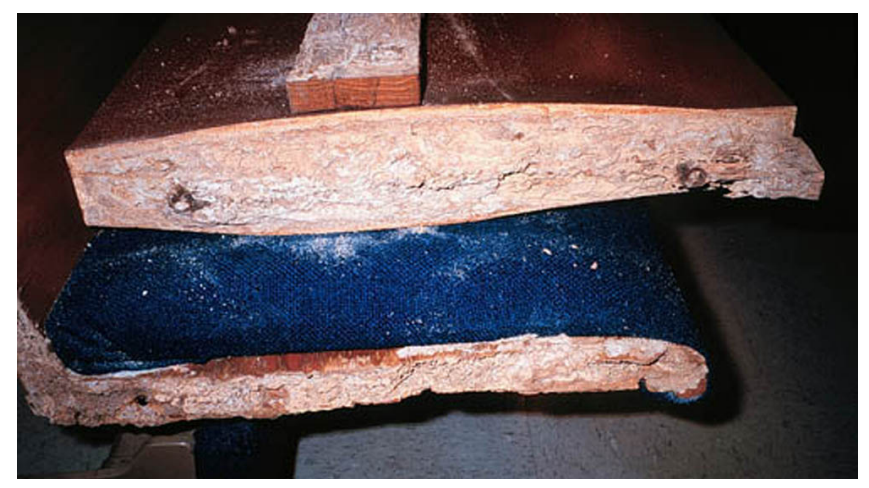

Figure 8. Damage by Coptotermes havilandi Holmgren to church pew, Miami. Credits: B. Maharajh

\section{Pest Status}

Infestations of $C$. havilandi in Florida are few and isolated at this time. Having demonstrated successful establishment in Florida indicates that this 


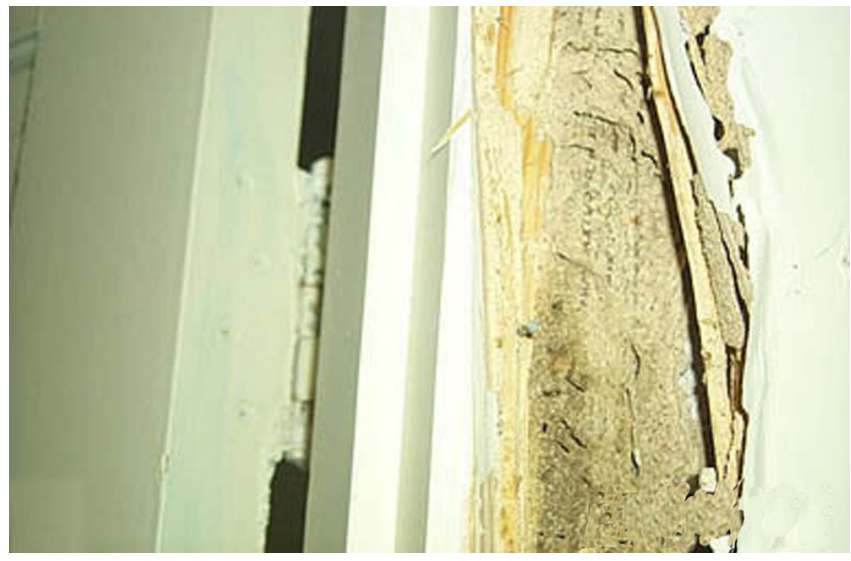

Figure 9. Carton material in door casing damaged by Coptotermes havilandi Holmgren, Key West. Credits: Mark Lang

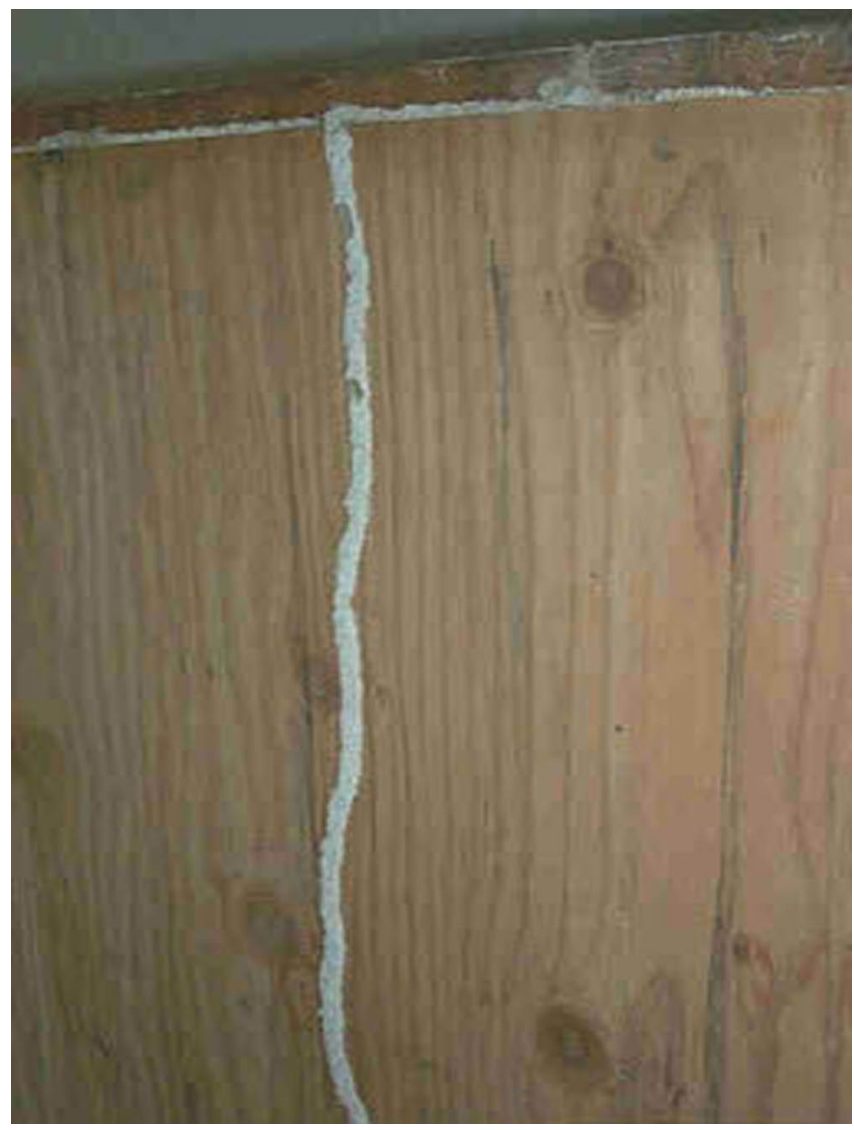

Figure 10. Foraging tube made with coral sand by Coptotermes havilandi Holmgren, Key West. Credits: Mark Lang

pest will become more widespread over time. Due to climatic restrictions, the future distribution of $C$. havilandi in the continental United States will probably not extend far beyond southern Florida. The importance of this pest is likely to increase in Puerto Rico and it may surface in Hawaii, the U.S. Virgin Islands, and other tropical territories in years to come.

\section{Management}

The same management strategies employed for C. formosanus should be considered for C. havilandi. The Sentricon ${ }^{\circledR}$ baiting system has been the only control technique specifically tested on $C$. havilandi and results confirm that this method is an effective means of control.

\section{Selected References}

Scheffrahn, R.H., N.-Y. Su, and B. Diehl. 1990. Native, introduced, and structure-infesting termites of the Turks and Caicos Islands, B.W.I. (Isoptera: Kalotermitidae, Rhinotermitidae, Termitidae). Florida Entomol. 73: 622-627.

Scheffrahn, R.H., and N. Su. (March 2000). Current distribution of the Formosan subterranean termite and Coptotermes havilandi in Florida. UF/IFAS. http://www.ftld.ufl.edu/bbv3n1.htm\#termite. (April 2000).

Su, N.-Y., P. M. Ban, and R. H. Scheffrahn. 2000. Control of Coptotermes havilandi (Isoptera: Rhinotermitidae) with hexaflumuron baits and a sensor incorporated into a monitoring-baiting program. J. Econ. Entomol. (93: 415-421).

Su, N.-Y., R.H. Scheffrahn, and T. Weissling. 1997. A new introduction of a subterranean termite, Coptotermes havilandi Holmgren (Isoptera: Rhinotermitidae) in Miami, Florida. Florida Entomol. 80: 408-411. 